\title{
The Important of Employee Retention Programs towards Bank Performance in East Coast, Malaysia
}

Nor Emmy Shuhada Derani ${ }^{1}$ \& Fadhilah Abdul Ghani ${ }^{2}$

${ }^{1 \& 2}$ Universiti Tenaga Nasional, Malaysia

\begin{tabular}{|c|c|}
\hline ARTICLE INFO & \multirow{13}{*}{$\begin{array}{l}\text { ABSTRACT } \\
\text { The purpose of this study is to explore the important of organizations' } \\
\text { retention programs towards improving firm performance in banking } \\
\text { sector. Almost every day, banking sector in Malaysia received } \\
\text { resignation letter from its employees. It's either from permanent or } \\
\text { contract basis employees. An organization underestimate this matter } \\
\text { and just take it for granted and it resulted bank performance decreased } \\
\text { as well as increasing in spending for new hiring. This study has been } \\
\text { conducted by distributing questionnaire to commercial and } \\
\text { conventional banks in East Coast, Malaysia. The findings displayed } \\
\text { the training and development, employee compensation, } \\
\text { communication in workplace and value in teamwork is crucial to retain } \\
\text { employees as well as to improve bank performance in Malaysia. Result } \\
\text { from this study will help management especially HR department to } \\
\text { look into retention programs seriously for the purpose of retaining its } \\
\text { staff and expertise. For future research, it has been recommended to } \\
\text { explore new industry such as manufacturing, hotel industry, retail as } \\
\text { well as telecommunication company due to these industries nowadays } \\
\text { shows high rate of turnover }\end{array}$} \\
\hline Article history: & \\
\hline Received: September 28, 2017 & \\
\hline 2017 & \\
\hline Accepted: Jan 2, 2018 & \\
\hline Keywords: & \\
\hline Banking, & \\
\hline Performance, & \\
\hline Retention, & \\
\hline & \\
\hline Clonflict of Interest: & \\
\hline None & \\
\hline & \\
\hline
\end{tabular}

None

Corresponding Author Nor Emmy Shuhada Derani, Email: emmy@uniten.edu.my

(C) Nor Emmy Shuhada Derani \& Fadhilah Abdul Ghani

This is an open access article under the CC BY-SA 4.0 international license.

\section{Introduction}

The benefit of retention program or practices provides firms with a wide-ranging set of mechanisms to vigorously manage employee turnover (Reiche, 2008). According to Ozolina-Ozola (2014), an effective human resource management directly have connections with employee turnover. Govaerts, Kyndt, Dochy, \& Baert, 2011; Hiltrop, 1999 (as cited by Pittino, Visintin, Lenger, \& Sternad, 2016) defined retention program as part of human resource management (HRM) practices that keeping talented individuals in an organization to maintain or remain competitive by avoiding turnover. This has been supported by Guthrie, 2001; Huselid, 1995; Shaw, Dineen, Fang, \& Vellella, 2009; Sun, Aryee, \& Law, 2007 who stated that turnover can affect an organization performance including its productivity as well as corporate financial performance (as cited by Pittino, Visintin, Lenger, \& Sternad, 2016).

In Malaysia, employee retentions remains a key challenges for any organization including small and medium enterprises (SMEs). This is because more employees are saying they are likely to leave their organization within two years (Towers Watson, 2015). However, retention program in Malaysia are still lacking due to lots of organizations in Malaysia assumes that retaining talents by an employees is always hard due to it leads to higher cost and most of the organizations prefer to ignore rather than to solve the retention program problems (Wee, 2013).

Nowadays, any present financial system or organization contributes to economic development as well as for an improvement in living standards by offering and providing various services to public and to the rest of the economy as a whole. This organization or financial system providing clearing and settlement to facilitate trade, channelling financial resources between debtors and creditors and also offering financial advises regarding various products and how to deal with risk and uncertainty in doing business transaction or daily transaction. 
Lebans \& Euske 2006 (as cited by Gavrea, Ilies, \& Stegerean, 2011) described performance as "a set of financial and nonfinancial indicators which offer information on the degree of achievement of objectives and results". While Neely, Gregory \& Platts (as cited by Al-Matari, Al-Swidi \& Fadzil (2014) support the study stated that in order to measure performance, an organization needs to measure the action's efficiency and effectiveness.

Positive and effective managerial practices are aim to increase employees' positive perceptions about organizational support which may help employees to develop positive feelings towards their employers and reduce their intention to quit from the job (Akgunduz \& Sanli, 2017). Trulson (2007) support the argument stating that retaining employees is essential for the organization success and suggests five methods that an organization must do for its success including "maintaining staffing levels, implementing team management, updating recruitment or screening process, addressing compensation issues, and professional development programs". Gberevie (2008) argued that employee retention is part of the organization's effort in order to reduce the substantial costs that involved in hiring and training new employees.

Abbasi \& Hollman (2000) argues that retention programs is essential and imperative especially in the banking industries because it will increase its productivity. In addition, employee turnover will increase when a firm do not provide retention programs to their employees (Abbasi \& Hollman, 2000). In this research, four independent variables (training and development, employee compensation, communication in the workplace and value of teamwork in workplace) were identified to examine its relationship towards dependent variable which is firm performance in banking industries. This study will contributed to banking industries in Malaysia by establishing a benchmark in creating and planning for retention program for employees' career development as well as helping an organization in reducing costs for new recruitment and avoiding employees turnover in future.

\section{Bank performance}

Johnson \& Noguera (2012) clarified that an organization are responsible in formulating excellent Human Resources Management (HRM) practices including enhancing an organization key performance indicator (KPI) to create good image of the firm and also creating more employee satisfaction while working in the organization. Khadka (2011) supported the argument stated that employee retention is crucial in HRM practices because employee retention activities resulted employees to perform their task effectively and efficiently while ensuring good jobs relation between employees and employer and also employee retention activites will maintaining a safe and healthy workplace.

\section{Training and Development and Firm Performance}

Williams \& Bokhorst-Heng (2016) stated that training and employee development is the most important elements in any business organization due to it will increase efficiency and commitment between employees and firm. Employee who undergo training will perform better due to they have upgrading their skills, knowledge and ability.

\section{Employees Compensation and Firm Performance}

Deysel \& Kruger (2015) argues that a good compensation packages interrelated in order to increase market capitalization and sustaining firm performance. This is because by managing effective compensation strategy as part of HRM function and practices, employees will improve its relationship with employer through exchange process whereby employees will provide good performance and productivity in accordance with skills and knowledge that they have and employer pay it with salary (Obasan, 2012). This has been supported by Moncarz, Zhao \& Kay (2009 who stated that compensation is important method leads to motivate employees to commit and enhance their attraction and retention.

\section{Communication in Workplace and Firm Performance}

Jones \& Kato (2003) stated that a good relationship between employer and employees is also important for firm performance. Employer who always communicate with their employees will resulted on better understanding in performing any task especially in improving quality of a firm (Brown, Gray, McHardy \& Taylor, 2015). Lahap, O’Mahony \& Dalrymple (2015) support this study by stating that two ways communication (bottom to up and up to bottom) is importance in enhancing service delivery and service quality by an employee towards its organization. 
Tohidi (2011) clarified that the most difficult task can be easily done if an employees received successful teamwork. Team can produce high productivity and outputs through teamwork and good collaboration (Manzoor, Ullah, Hussain \& Ahmad, 2011). This is because teamwork consists of various knowledge, skills and abilities that provide positive results especially in completing tasks (Hartenian, 2003).

\section{Research Methodology}

The quantitative research has been used to conduct this study where a sample of 200 questionnaires has been distributed in banking industries in East Coast, Malaysia including Terengganu, Pahang and Kelantan. Commercial and conventional banks has been chosen focusing on Maybank (Malayan Banking Berhad), CIMB Bank, RHB Bank, HSBC, BSN (Bank Simpanan Nasional), Bank Islam Malaysia Berhad (BIMB), Affin Bank, Bank Rakyat (Bank Kerjasama Rakyat Malaysia), Agro Bank and Public Bank. However, only 182 questionnaires were returned. Non-probability sampling methods which is convenience sampling has been chose for conducting this study. Duration process for data collection is two weeks from $16^{\text {th }}$ January until $27^{\text {th }}$ January 2017.

Instrumentation that has been used for this study including training and development, employee compensation, communication in workplace and value of teamwork in organization. Each variable are measured using six point Likert scales. Respondents were requested to indicate (1) not applicable, (2) strongly disagree, (3) disagree, (4) neutral, (5) agree and (6) strongly agree. In this study, Statistical Package for Social Science (SPSS version 23) will use to interpret reliability and correlation test as well as to process the data that has been collected. The results from SPSS also will be use to answer the relationship between independent and dependent variable.

Method of analysis that has been conducted in this study including descriptive analysis, reliability analysis and also correlation analysis. Descriptive analysis used in this study to analyse the pattern of respondents' background (demographic data). Normally, descriptive statistics encompass the following areas like frequency of distribution, measures of tendency and also measure of dispersion or variability. In other hands, correlation analysis refers to the any board class of statistical relationships involving any statistical relationship between two random variables or two sets of data. Correlation analysis has been use to test whether the relationship is exist between retention program and bank performance. While reliability analysis has been carried out for this study to determine internal consistency for the elements that has been used. Therefore, Cronbach's coefficients alpha will compute to ascertain the factor reliability and indicates how well the items in a set are positively correlated to one another.

Research framework

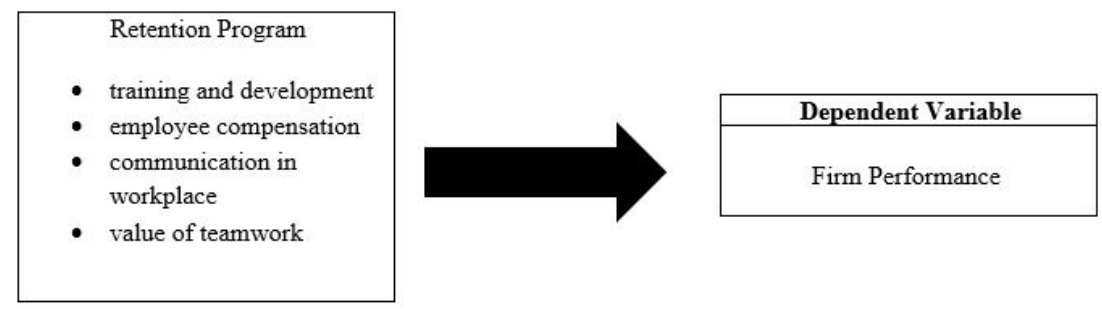

Figure 1: Research Framework

\section{Hypothesis}

Our hypotheses for this study are as follows:

H1: There is a positive relationship between training and development and firm performance.

$\mathrm{H} 2$ : There is a positive relationship between employee compensation and firm performance.

H3: There is a positive relationship between communication in workplace and firm performance.

H4: There is a positive relationship between value of teamwork and firm performance.

\section{Discussion and Recommendation}

From the table, it can conclude that all the variables are reliable as the Cronbach's alpha coefficient show a relatively high consistency.

Table 1: Reliability Statisctic 


\begin{tabular}{|c|c|c|}
\hline $\begin{array}{c}\text { Cronbach's } \\
\text { Alpha }\end{array}$ & N of Items & Variable \\
\hline .863 & 6 & Training and development \\
\hline .885 & 5 & Employee compensation \\
\hline .879 & 5 & $\begin{array}{c}\text { Communication in } \\
\text { workplace }\end{array}$ \\
\hline .853 & 5 & Value of teamwork \\
\hline .900 & 5 & Firm performance \\
\hline
\end{tabular}

\section{Descriptive analysis}

For descriptive analysis, data shows that female respondents represent $52.7 \%$ while male respondents $47.3 \%$. From the respondents, $11 \%$ are less than 25 years old, followed by $44.5 \%$ aged 26 to 35 years old, $31.9 \%$ aged 36 until 45 years old, and another $12.6 \%$ are aged from 45 and above. Respondents for this study are mostly from Malays (90.1\%), followed by Indian (5.5\%) and Chinese (4.4\%). Respondents also been requested to answer their marital status. From the data gathered, $73.1 \%$ married and $26.9 \%$ are single. For the numbers of year service in the respective banks, result shows that $47.8 \%$ has been working for more than six years, $25.8 \%$ have served the company for four until six years, followed by $22 \%$ for respondents who work between one until 3 years and $4.4 \%$ shows that respondents work less than one year. Respondents are from executive level equal to $36.8 \%$, followed by non-executive (52.2\%) and managerial level (11\%).

\section{Correlation analysis}

Table 2: Summary for correlation value for all variables in this study.

\begin{tabular}{|c|c|c|c|c|c|c|}
\hline & & $\mathrm{T} \& \mathrm{D}$ & $\begin{array}{c}\text { Compensati } \\
\text { on }\end{array}$ & Comm & Teamwork & \begin{tabular}{c|c|} 
Firm \\
Performance
\end{tabular} \\
\hline \multirow[t]{3}{*}{$T \& D$} & $\begin{array}{l}\text { Pearson } \\
\text { Correlation }\end{array}$ & 1 & $.637^{* *}$ & $.489^{\circ *}$ & $.593^{\circ *}$ & $.585^{\circ *}$ \\
\hline & $\begin{array}{l}\text { Sig. (2- } \\
\text { tailed) }\end{array}$ & & .000 & .000 & .000 & .000 \\
\hline & $\mathrm{N}$ & 182 & 182 & 182 & 182 & 182 \\
\hline \multirow[t]{3}{*}{ Compensation } & $\begin{array}{l}\text { Pearson } \\
\text { Correlation }\end{array}$ & $.637^{*}$ & 1 & $.710^{* *}$ & $.724^{* *}$ & $.733^{* *}$ \\
\hline & $\begin{array}{l}\text { Sig. (2- } \\
\text { tailed) }\end{array}$ & .000 & & .000 & .000 & .000 \\
\hline & $\mathrm{N}$ & 182 & 182 & 182 & 182 & 182 \\
\hline \multirow[t]{3}{*}{ Comm } & $\begin{array}{l}\text { Pearson } \\
\text { Correlation }\end{array}$ & $.489^{\circ-}$ & $.710^{\circ *}$ & 1 & $.764^{* *}$ & $.745^{* *}$ \\
\hline & $\begin{array}{l}\text { Sig. (2- } \\
\text { tailed) }\end{array}$ & .000 & .000 & & .000 & .000 \\
\hline & $\mathrm{N}$ & 182 & 182 & 182 & 182 & 182 \\
\hline \multirow[t]{3}{*}{ Teamwork } & $\begin{array}{l}\text { Pearson } \\
\text { Correlation }\end{array}$ & $.593^{*}$ & $.724^{* *}$ & $.764^{* *}$ & 1 & $.696^{* *}$ \\
\hline & $\begin{array}{l}\text { Sig. (2- } \\
\text { tailed) }\end{array}$ & .000 & .000 & .000 & & .000 \\
\hline & $\mathrm{N}$ & 182 & 182 & 182 & 182 & 182 \\
\hline \multirow[t]{3}{*}{$\begin{array}{l}\text { Firm } \\
\text { Performance }\end{array}$} & $\begin{array}{l}\text { Pearson } \\
\text { Correlation }\end{array}$ & $.585^{* *}$ & $.733^{* *}$ & $.745^{\circ *}$ & $.696^{* *}$ & 1 \\
\hline & $\begin{array}{l}\text { Sig. (2- } \\
\text { tailed) }\end{array}$ & .000 & .000 & .000 & .000 & \\
\hline & $\mathrm{N}$ & 182 & 182 & 182 & 182 & 182 \\
\hline
\end{tabular}

Hypothesis 1: There is a positive relationship between training and development and firm performance.

Findings shows that $\mathrm{r}=0.585^{* *}, \mathrm{~N}=182$ for the relationship between training and development and firm performance. Based on Pearson (1895), we can conclude that training and development and firm performance has strong relationship. Weru, Iravo, \& Sakwa, (2013) support this hypothesis by stated that almost organizations nowadays involving in international business by expanding business to the foreign countries and training and development functions by offering an interesting case of change for any organization in facing 
with uncertainty and rapidly changing environment for improving organization's performance and effectiveness.

Hypothesis 2: There is a positive relationship between employee compensation and firm performance.

Data gathered shows that $\mathrm{r}=0.733^{*}, \mathrm{~N}=182$. It shows that employee compensation has very strong relationship with firm performance. This study aligned with Aduda (2011) stated that bank can perform better through employees who satisfied with their compensation. Demirer \& Yuan (2011) support the argument clarified that employees want to return its skills and ability with good bonus, allowance and other benefits from the company they work.

Hypothesis 3: There is a positive relationship between communication in workplace and firm performance.

From the statistical result shown that $\mathrm{r}=0.745^{* *}, \mathrm{~N}=182$ meaning that communication in workplace has very strong relationship with firm performance. We can conclude that when employees and employer has good communication in workplace, it will resulted on quality improvement and productivity (Jones \& Kato, 2003).

Hypothesis 4: There is a positive relationship between value of teamwork and firm performance.

From the statistical result shown that $\mathrm{r}=0.696, \mathrm{~N}=182$. From the analysis, the relationship between value of teamwork and firm performance is strong relationship. Manzoor et al., (2011) support the argument stating that an organization's productivity will increase if employee and employers work together.

\section{Limitation}

Although this study has reached its aims, there were some unavoidable limitations and gap that faced by the researchers. First, due to time constraint, this study was conducted only in East Coast Malaysia including Pahang, Kelantan and Terengganu by focusing on all levels in particular banks. Therefore, to generalize the results, this study should involve all employees in all states in Malaysia. Next limitation is, lack of variables to support the study. For this research, four independent variables has been used. These independent variables probably not applicable for certain employees especially in lower level. Therefore, researchers should considered any other independent variables that may represent all employees.

To compare and analyze the important of retention programs in future, other industries sectors such as retailing or telecommunication may be the best population to look into since both industries currently shows high turnover especially in challenging era and critical economy conditions nowadays including involving all states in Malaysia.

\section{Contribution}

Banking industries in Malaysia

Banking industries is one of the main pillars of the social and economic system in Malaysia. In addition, banking industries contribute to the overall economy as well as towards the society with its service and various products. Practically, this study will help top management in banking industries to apply good HR practices especially for organization retention programs. Any banks in Malaysia benefited from losing employees who have intention to resign and this resulted in reduce the percentage of employee turnover whilst minimizing organizations' cost for new hiring including training and so on.

\section{Academic or scholars}

Theoretically, this study also important for scholars in related fields such as finance, economic as well as management. This research contributed in the way of the current trend that employees currently feels about retention programs. More arguments will be debated in order to get reliable and significant analysis in future

\section{Conclusion}

From the results, it showed that retention program (training and development, employee compensation, communication in workplace and value of teamwork) has a positive relationship with bank performance with high consistency and the result has been supported by the previous scholars. Therefore and organization especially HR Department should look into this matter to provide baseline for their employees. Compensation for employees and communication in workplace is crucial in banking industries to reduce number of turnover as well as in increasing organization's productivity. 


\section{References}

Abbasi, S. M., \& Hollman, K. W. (2000). Turnover: The real bottom line. Public Personnel Management, 29(3), 333-342.

Aduda, J. (2011). The relationship between executive compensation and firm performance in the Kenyan banking sector. Journal of Accounting and Taxation, 3(6), 130.

Akgunduz, Y., \& Sanli, S. C. (2017). The effect of employee advocacy and perceived organizational support on job embeddedness and turnover intention in hotels. Journal of Hospitality and Tourism Management, 31, 118-125.

Al-Matari, E. M., Al-Swidi, A. K., \& Fadzil, F. H. B. (2014). The measurements of firm performance's dimensions. Asian Journal of Finance \& Accounting, 6(1), 24-49.

Brown, S., Gray, D., McHardy, J., \& Taylor, K. (2015). Employee trust and workplace performance. Journal of Economic Behavior \& Organization, 116, 361-378.

Gavrea, C., Ilies, L., \& Stegerean, R. (2011). Determinants of organizational performance: The case of Romania. Management \& Marketing, 6(2), 285.

Demirer, I., \& Yuan, J. J. (2011). Executive compensation and firm performance in the US restaurant industry: An agency theory approach.

Deysel, B., \& Kruger, J. (2015). The relationship between South African CEO Compensation and company performance in the banking industry. Southern African Business Review, 19(1), 137-169.

Gberevbie, D. E. (2008). Staff recruitment, retention strategies and performance of selected public and private organizations in Nigeria (Doctoral dissertation, Covenant University Ota).

Hartenian, L. S. (2003). Team member acquisition of team knowledge, skills, and abilities. Team Performance Management: An International Journal, 9(1/2), 23-30.

Johnson, R. C., \& Noguera, G. (2012). Accounting for intermediates: Production sharing and trade in value added. Journal of international Economics, 86(2), 224-236.

Jones, D. C., \& Kato, T. (2003). The effects of employee involvement on firm performance: evidence from an econometric case study.

Khadka, S. (2011). Employee retention in banking industry of Nepal. Rajasthan, India. Singhania University.

Lahap, J., O’Mahony, B., \& Dalrymple, J. (2016). The Importance of Communication in Improving Service Delivery and Service Quality in the Malaysian Hotel Industry. Procedia-Social and Behavioral Sciences, 224, 213-220.

Long, C. S., Ajagbe, M. A., \& Kowang, T. O. (2014). Addressing the Issues on Employees' Turnover Intention in the Perspective of HRM Practices in SME. Procedia-Social and Behavioral Sciences, 129, 99104.

Manzoor, S. R., Ullah, H., Hussain, M., \& Ahmad, Z. M. (2011). Effect of teamwork on employee performance. International Journal of Learning and Development, 1(1), 110-126.

Mehta, M., Kurbetti, A., \& Dhankhar, R. (2014). Review Paper-Study on Employee Retention and Commitment. International journal of advance research in computer science and management studies, 154(5).

Moncarz, E., Zhao, J., \& Kay, C. (2009). An exploratory study of US lodging properties' organizational practices on employee turnover and retention. International Journal of Contemporary Hospitality Management, 21(4), 437-458.

Obasan, K. A. (2012). Effect of compensation strategy on corporate performance: Evidence from Nigerian firms. Research Journal of Finance and Accounting, 3(7), 37-44.

Ozolina-Ozola, I. (2014). The impact of human resource management practices on employee turnover. Procedia-Social and Behavioral Sciences, 156, 223-226.

Pearson, K. (1895). Note on regression and inheritance in the case of two parents. Proceedings of the Royal Society of London, 58, 240-242.

Pittino, D., Visintin, F., Lenger, T., \& Sternad, D. (2016). Are high performance work practices really necessary in family SMEs? An analysis of the impact on employee retention. Journal of Family Business Strategy, 7(2), 75-89.

Reiche, B. S. (2008). The configuration of employee retention practices in multinational corporations' foreign subsidiaries. International Business Review, 17(6), 676-687.

Tohidi, H. (2011). Human Resources Management main role in Information Technology project management. Procedia Computer Science, 3, 925-929.

Trulson, C. R. (2007). Determinants of disruption: Institutional misconduct among state-committed delinquents. Youth Violence and Juvenile Justice, 5(1), 7-34.

Wee, T. C. (2013). Talent Retention: The Pressures in Malaysia SMEs. American Journal of Economics, 3(C), $35-40$.

ASHREJ Vol. 1, No. 2, 2019: 19-25 
Weru, J. W., Iravo, M. A., \& Sakwa, M. (2013). The Relationship between Training and Development on Performance of State Owned Corporations. International Journal of Academic Research in Business and Social Sciences, 3(9), 57.

Williams, J. H., \& Bokhorst-Heng, W. D. (Eds.). (2016). (Re) Constructing Memory: Textbooks, Identity, Nation, and State. Springer. 